\title{
PEMBERDAYAAN MASYARAKAT DALAM UPAYA PENGEMBANGAN POTENSI AGRIBISNIS DI DESA POHSANTEN KECAMATAN MENDOYO KABUPATEN JEMBRANA
}

\author{
W. Widhiada ${ }^{1}$ dan C.G.I. Partha ${ }^{2}$
}

\begin{abstract}
ABSTRAK
Desa Pohsanten memiliki potensi besar dalam bidang pertanian dan peternakan. Potensi komoditi buahbuahan sangat besar sehingga mampu membantu perekonomian masyarakat desa seperti potensi tanaman kakao. Prospek bisnis kakao menarik minat masyarakat untuk dibudidayakan dan diolah menjadi produk yang bernilai tinggi. Namun kelompok tani ini belum mengetahui dengan baik bagaimana cara pengolahan buah kakao dengan benar sehingga hasil yang diperoleh masyarakat juga tidak meningkat. Potensi energi alternatif dari biogas kotoran sapi sebenarnya sangat tinggi, tetapi gapoktan belum memanfaatkannya secara optimal, walaupun disana sudah terdapat instalasi pengolahan biogas. Salah satu penyebabnya adalah biogas yang dihasilkan masih mengandung $\mathrm{H}_{2} \mathrm{~S}$ dan menyebabkan alat-alat biogas tersebut cepat korosi. Metode pelaksanaan kegiatan dibagi menjadi tiga tahapan. Tahapan pertama adalah persiapan dan pembekalan, tahap kedua implementasi kegiatan di lapangan, dan tahap ketiga evaluasi dan monitoring keberlanjutan program. Tahap persiapan dimulai dengan dosen pembimbing lapangan dan mahasiswa audensi dengan aparat desa dan tokoh masyarakat untuk menentukan skala prioritas kegiatan berdasarkan kondisi dan potensi yang ada di masyarakat. Tahap implementasi pelaksanaan kegiatan dilakukan dengan penyuluhan maupun praktek di lapangan. Sedangkan tahap ketiga adalah evaluasi dan monitoring dilakukan oleh tim pelaksana/dosen pembimbing lapangan dan koordinator KKN untuk melihat dampak dan keberlanjutan program yang sudah dilaksanakan.
\end{abstract}

Kata Kunci : Pembedayaan, Potensi Agribisnis, Energi alternative, Biogas, Buah Kakao

\begin{abstract}
Pohsanten village has great potential in agriculture and livestock. The potential of cocoa fruits commodity is so large that it is able to assist the economy of the village community. The business prospects of cocoa attract people to be cultivated and processed into high value products. However, this farmer group does not know well how to process cocoa fruit properly so that the results obtained by the community also did not increase. The potential of biogas energy alternative is actually very high, but the group of Gapoktan has not utilized it optimally, although there is already a biogas processing plant. One of the causes is that the biogas produced still contains H2S and causes the biogas tools to quickly corrode. There are three stages of research methods. The first stage is preparation and briefing, second phase of implementation of activities in the field, and third stage of evaluation and monitoring of program sustainability. The preparatory phase begins with field supervisors and student auditors with village officials and community leaders to determine the priority scale of activities based on existing conditions and potentials in the community. Implementation phase of the implementation of activities carried out by extension and practice in the field. The third stage is the evaluation and monitoring conducted by the team of field supervisors and coordinators of KKN to see the impact and sustainability of programs that have been implemented.
\end{abstract}

Keywords: Empowerment, Agribusiness Potential, Alternative Energy, Biogas, Cocoa Fruit

\footnotetext{
${ }^{1}$ Staf Pengajar Jurusan Teknik Mesin Fakultas Teknik Universitas Udayana, cokindra@unud.ac.id

${ }^{2}$ Staft Pengajar Jurusan Teknik Elektro Fakultas Teknik Universitas Udayana, @yahoo.com
} 


\section{PENDAhUluaN}

Kuliah Kerja Nyata Pembelajaran Pemberdayaan Masyarakat (KKN PPM) merupakan suatu kegiatan intrakurikuler yang memadukan Tri Dharma Perguruan Tinggi dengan metode pemberian pengalaman belajar dan bekerja kepada mahasiswa dalam upaya pemberdayaan masyarakat. KKN PPM juga merupakan wahana penerapan dan pengembangan ilmu pengetahuan dan teknologi yang mengarah pada keterkaitan antara akademik-teoritik dan dunia empirik-praktis. Dengan hal tersebut maka akan terjadi interaksi sinergis, dan simbiosis mutualisme antara mahasiswa dan masyarakat.

Salah satu daerah yang dijadikan sebagai daerah KKN PPM Periode XV tahun 2017 adalah Desa Pohsanten yang terletak di Kecamatan Mendoyo, Kabupaten Jembrana, Provinsi Bali. Desa Pohsanten terletak di Kecamatan Mendoyo, Kabupaten Jembrana dengan luas wilayah desa 3.050 ha. Berdasarkan titik koordinat, Desa Pohsanten terletak di 8,3195 S dan 114,6876 E. Desa Pohsanten berada di dataran rendah hingga perbukitan yang memiliki ketinggian $\pm 1.250 \mathrm{~m}$ di atas permukaan air laut dengan suhu berkisar antara $20^{\circ} \mathrm{C}$ hingga $27^{\circ} \mathrm{C}$. Desa Pohsanten terdiri atas lima banjar yaitu Banjar Munduk, Banjar Rangdu, Banjar Dangin Pangkung Jangu, Banjar Dauh Pangkung Jangu, dan Banjar Pasatan. Desa Pohsanten berbatasan dengan hutan Negara di sebelah utara, sebelah timur berbatasan dengan Desa Pergung, sebelah selatan berbatasan dengan Desa Mendoyo Dangin Tukad, dan sebelah barat berbatasan dengan Desa Mendoyo Dauh Tukad.

Penduduk Desa Pohsanten mayoritas bekerja sebagai petani dan pekebun. Di Banjar Pasatan terdapat banyak perkebunan yang menghasilkan beranekaragam produk hasil tanaman seperti cengkeh, kelapa, dan kakao. Produk unggulan perkebunan Desa Pohsanten adalah kakao yang sudah terkenal hingga mancanegara karena memiliki kualitas tinggi dengan tiga cita rasa yaitu pahit, manis dan asam. Kakao di daerah ini merupakan salah satu kakao berkualitas tinggi yang di ekspor hingga keluar negeri. Prospek bisnis kakao menarik minat masyarakat untuk dibudidayakan dan diolah menjadi produk yang bernilai tinggi. Namun kelompok tani ini belum mengetahui dengan baik bagaimana cara pengolahan buah kakao dengan benar sehingga hasil yang diperoleh masyarakat juga tidak meningkat.

Selain bertani dan berkebun, terdapat kelompok masyarakat yang bekerja sebagai peternak sapi (Soebarinoto, 1997) ataupun kambing yang sering disebut dengan kelompok SIMANTRI (Sistem Pertanian Terintegrasi). Potensi energi alternatif dari biogas kotoran sapi sebenarnya sangat tinggi, tetapi Gapoktan belum memanfaatkannya secara optimal, walaupun disana sudah terdapat instalasi pengolahan biogas. Salah satu penyebabnya adalah biogas yang dihasilkan masih mengandung $\mathrm{H}_{2} \mathrm{~S}$ dan menyebabkan alat-alat biogas tersebut cepat korosi.

Metode pelaksanaan kegiatan dibagi menjadi tiga tahapan. Tahapan pertama adalah persiapan dan pembekalan, tahap kedua implementasi kegiatan di lapangan, dan tahap ketiga evaluasi dan monitoring keberlanjutan program. Tahap persiapan dimulai dengan dosen pembimbing lapangan dan mahasiswa audensi dengan aparat desa dan tokoh masyarakat untuk menentukan skala prioritas kegiatan berdasarkan kondisi dan potensi yang ada di masyarakat. Tahap implementasi pelaksanaan kegiatan dilakukan dengan penyuluhan maupun praktek di lapangan. Sedangkan tahap ketiga adalah evaluasi dan monitoring dilakukan oleh tim pelaksana/dosen pembimbing lapangan dan koordinator KKN untuk melihat dampak dan keberlanjutan program yang sudah dilaksanakan. 


\section{METODE PELAKSANAN DAN HASIL KEGIATAN}

\subsection{Deskripsi Kegiatan Pengolahan Buah Kakao}

Kegiatan Penyuluhan Tentang Potensi, Manfaat dan Limbah Hasil Buah Kakao dilaksanakan dengan tujuan untuk memberikan informasi dan pembelajaran kepada petani kakao yang ada di Desa Pohsanten, Kecamatan Mendoyo, Kabupaten Jembrana tentang potensi, manfaat dan limbah buah kakao agar dapat dibudidayakan secara maksimal mulai dari pra hingga pasca panen sehingga diharapkan dapat meningkatkan taraf hidup petani kakao yang ada di Desa Pohsanten.

Proses awal pelaksanaan kegiatan ini yang pertama adalah melakukan survei lapangan / survei lokasi ke kebun kakao yang terdapat di Banjar Pasatan untuk mengetahui kendala dan permasalahan yang dihadapi di lapangan seperti serangan penyakit serta faktor cuaca yang mempengaruhi proses produksi buah kakao sehingga tidak mendapatkan hasil buah kakao dengan kualitas yang diharapkan. Setelah didapatkan permasalahan yang ada di lapangan, langkah selanjutnya adalah mengirimkan surat serta melakukan audiensi dengan pihak dinas pertanian bidang perkebunan untuk membicarakan tentang materi yang akan disampaikan terkait tema dan permasalahan yang dihadapi oleh petani buah kakao yang ada di Desa Pohsanten. Setelah itu dilaksanakan kegiatan Penyuluhan Tentang Potensi, Manfaat dan Limbah Hasil Buah Kakao yang dibuka oleh Kepala Desa Pohsanten yang dihadiri oleh Bendesa Adat, Pejabat Desa, Kelian Adat, Kelian Banjar, Kelian Subak, Babinsa dan Babinkamtibmas serta Petani Buah Kakao Banjar Pasatan yang terdiri dari 2 kelompok yaitu Kelompok Petani Kakao Dwimekar dan Amertha Urip.

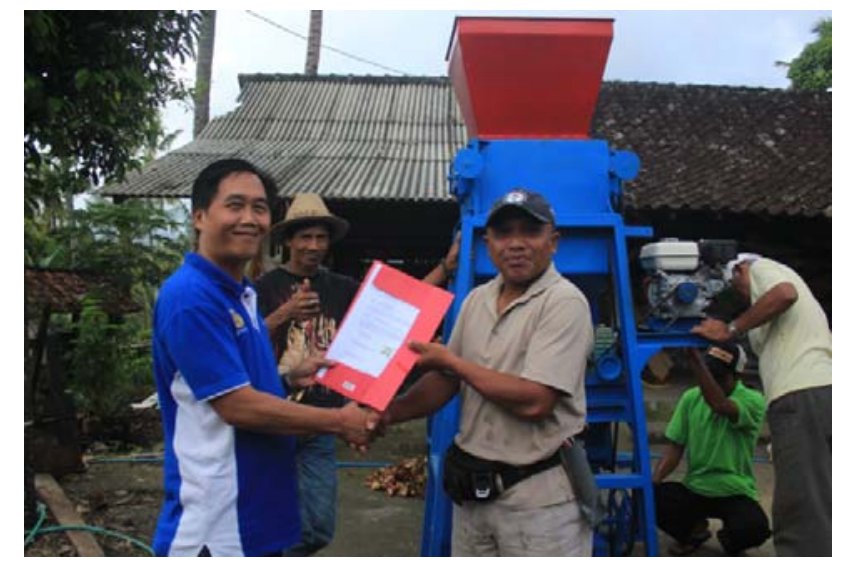

Gambar 2.1. Penyerahan Satu Unit Mesin Pemecah Buah Kakao Dan Pemisah Biji Kakao.

\subsection{Hasil Kegiatan Pengolahan Buah Kakao}

Hasil atau output dari kegiatan Penyuluhan Tentang Potensi, Manfaat dan Limbah Hasil Buah Kakao adalah semakin bertambahnya wawasan para petani kakao di Desa Pohsanten mengenai potensi, manfaat serta pengelolaan limbah hasil dari buah kakao mereka sehingga diharapkan dapat semakin meningkatkan hasil produksinya. Serta mendapatkan solusi atas masalah yang dihadapi di lapangan seperti penyakit yang menyerang buah kakao mereka dan kendala cuaca yang menyebabkan sulitnya pengeringan biji buah kakao dalam proses pengelolaan pasca panen sebelum dijual dan diekspor ke luar negeri. Sehingga dapat dilakukan tindakan pengobatan dan pencegahan untuk mengatasi masalah tersebut seperti melakukan penyemprotan serta pengeringan secara tepat guna. Selain itu juga didapatkan informasi bahwa budidaya buah kakao yang ada di Desa Pohsanten telah 
mendapatkan sertifikasi organik yang diakui secara Internasional dan merupakan penghasil produksi buah kakao terbesar kedua secara di Indonesia.

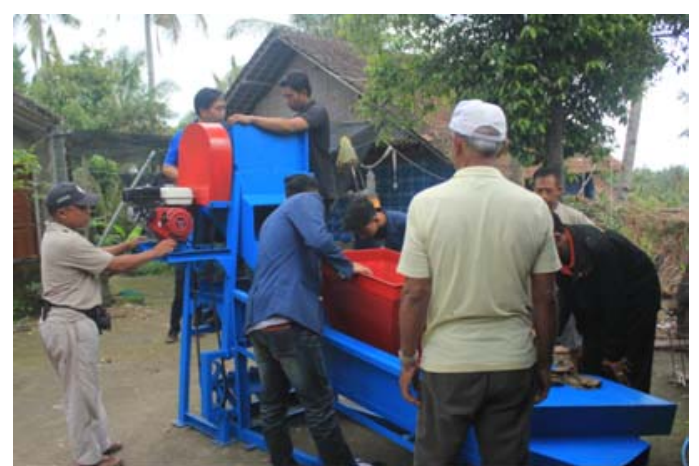

Gambar 2.2. Proses pengoperasian mesin pemecah dan pemisah biji Kakao.

Setelah dilakukan kegiatan Penyuluhan Tentang Potensi, Manfaat dan Limbah Hasil Buah Kakao. Tindak lanjut dari kegiatan tersebut adalah, dari pihak DPL dan mahasiswa KKN memberikan bantuan berupa alat / mesin pemecah dan pemisah buah kakao. Dengan adanya alat tersebut diharapkan dapat mempermudah dalam kegiatan produksi buah kakao sehingga bisa lebih mengefisensi waktu. Alat / mesin tersebut didatangkan dari Bekasi dan sampai di Desa Pohsanten pada tanggal 21 Agustus 2017 dan langsung ditempatkan di rumah Bapak Made Sugandi Ketua Kelompok Kakao Amertha Urip. Praktek dilakukan besoknya oleh DPL Desa Pohsanten berserta tim mahasiswa untuk merakit alat / mesin yang sudah disapkan.

\subsection{Deskripsi Pengolahan Energi Biogas}

Kegiatan penyuluhan manfaat kotoran ternak dilaksanakan oleh mahasiswa KKN, yang mana pesertanya adalah Ketua SIMANTRI 222 beserta beberapa anggota SIMANTRI 222. Kegiatan penyuluhan ini dihadiri pula oleh perangkat Desa Pohsanten. Kegiatan penyuluhan manfaat kotoran ternak [Astawa dkk., 2013] dilaksanakan di Aula Kantor LPD Desa Pohsanten mulai Pukul 09.30 wita dan berakhir pada pukul 12.30 wita. Dalam kegiatan penyuluhan ini, disampaikan mengenai optimalisasi pemanfaatan biogas. Materi penyuluhan yang dipilih yaitu optimalisasi pemanfaatan biogas, hal tersebut berdasarkan pertimbangan bahwa adanya mesin pengolahan kotoran sapi untuk menjadi Biogas di SIMANTRI 222 hanya dimanfaatkan untuk menghidupkan kompor padahal biogas tersebut dapat digunakan pula untuk menghidupkan listrik dan pompa air (Sunaryo, 2014).

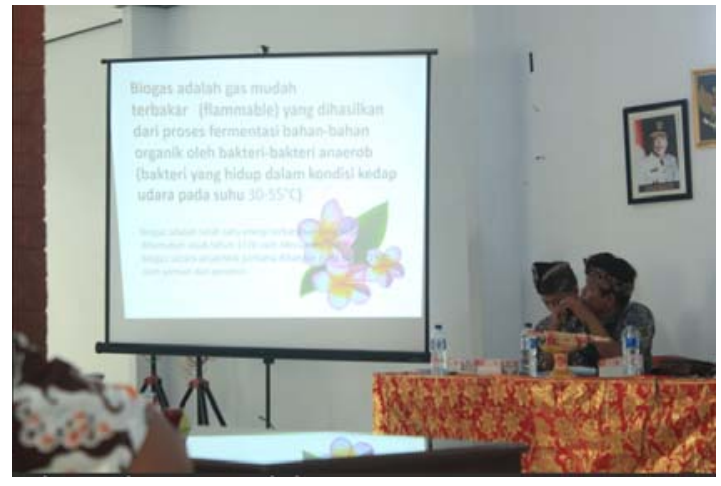

Gambar 2.3. Kegiatan Penyuluhan manfaat Kotoran trenak sebagai penghasil biogas 
Kegiatan Praktik Pendistribusian Biogas dilakukan di SIMANTRI 222 Desa Pohsanten yang dilaksanakan oleh mahasiswa KKN dan dihadiri oleh Ketua SIMANTRI 222 beserta beberapa anggota SIMANTRI 222. Kegiatan praktik pembuatan biogas ini dilaksanakan 2 kali yakni pada tanggal 24 Juli 2017 dan 8 Agustus 2017. Praktik pertama pada tanggal 24 Juli 2017 dihadiri pula oleh Prof. Tjokorda Tirta Nindhi dan beberapa mahasiswa Teknik Mesin. Kegiatan praktik pembuatan biogas pertama dilaksanakan mulai Pukul 15.00 wita dan berakhir pada pukul 19.00 wita. Dalam kegiatan praktik ini, mahasiswa Teknik mesin memasang alat yang disebut "Disulfur" pada pipa yang menyalurkan Biogas. Kemudian dilanjutkan dengan proses perubahan kotoran sapi menjadi biogas yang diolah dalam gester dan kemudian disalurkan melalui pipa sampai akhirnya dapat digunakan untuk menghidupkan api di kompor. Kompor yang digunakan adalah kompor khusus biogas.

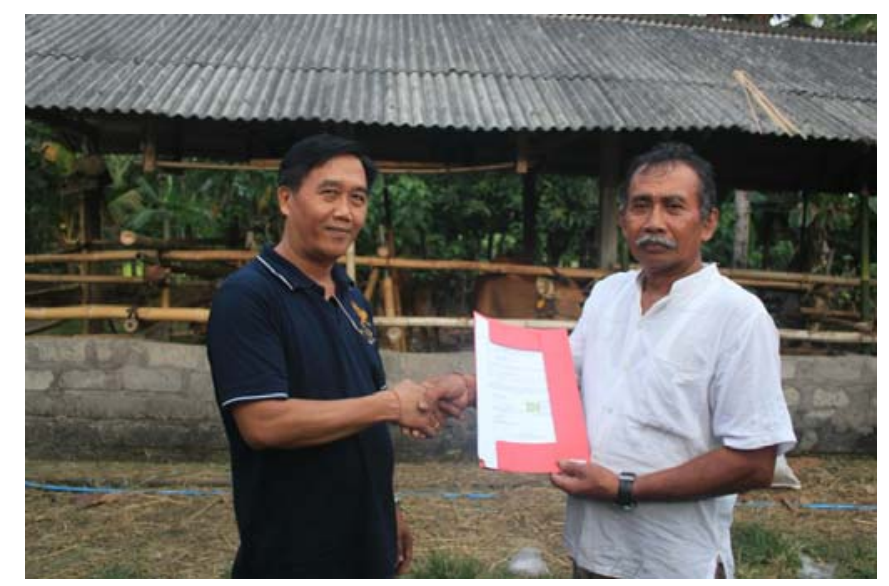

Gambar 2.4. Penyerahan unit mesin pengolah biogas menjadi energy terbarukan

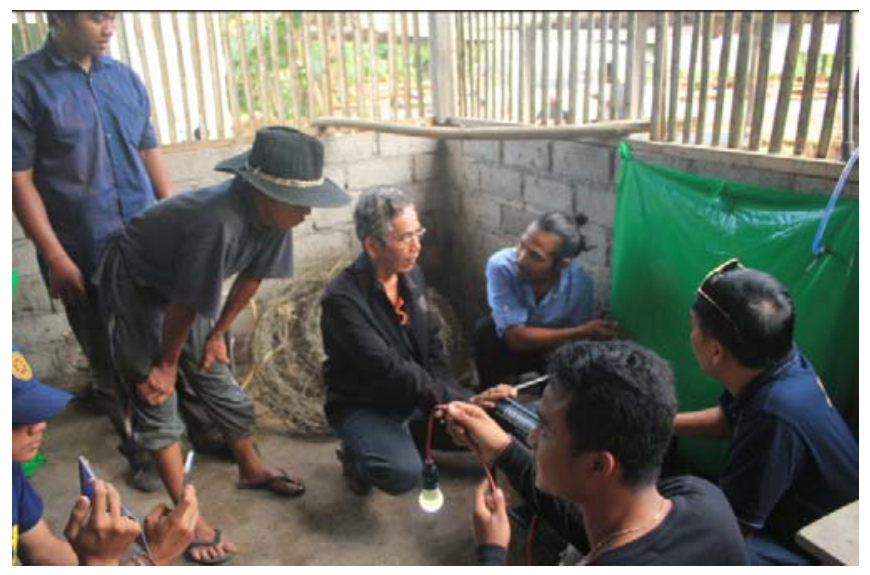

Gambar 2.5. Proses pengoperasian mesin teknologi biogas

Pada praktik kedua pada tanggal 8 Agustus 2017, praktik yang dilakukan adalah memanfaatkan biogas tidak hanya untuk kompor tetapi juga untuk menghidupkan lampu dan pompa air serta menyalakan alat bor kayu dengan menggunakan sumber listik dari alat biogas. Dan praktik penggunaan alat berjalan dengan lancar. 


\subsection{Hasil Kegiatan Pengolahan Energi Biogas}

Kegiatan penyuluhan manfaat kotoran ternak yang dilaksanakan pada Kamis, 27 Juli 2017 berlangsung dengan lancar. Penyuluhan manfaat kotoran ternak dibuka oleh Jro Bendesa Pohsanten sebagai perwakilan Desa, kemudian acara penyuluhan dilanjutkan dengan penyampaian materi dan sesi tanya jawab. Penyuluhan manfaat kotoran ternak ditutup dengan foto bersama oleh pembicara, peserta serta mahasiswa KKN.

Setelah dilakukannya penyuluhan, pada praktek biogas berikutnya SIMANTRI tidak hanya memanfaatkan biogas untuk menghidupkan kompor, tetapi juga untuk menyalakan lampu dan mencoba memanfaatkannya terkait pompa air.

\section{KESIMPULAN}

Kesimpulan yang dapat ditarik dalam pelaksanaan program KKN PPM Universitas Udayana periode XV di Desa Pohsanten adalah sebagai berikut :

1. Mengaplikasikan teknologi terbaharukan pengolah energi biogas menjadi energi terbarukan yang ramah lingkungan kepada kelompok SIMANTRI 222.

2. Mengaplikasikan mesin pemecah dan pemisah buah kakao pada kelompok petani kakao untuk dapat meningkatkan produksi biji kakao sehingga memiliki nilai jual tinggi.

3. Memberdayakan masyarakat Desa Pohsanten menjadi masyarakat yang Mandiri, mandiri dalam artian dapat memanagemen hidupnya dan dapat menciptakan kesejahteraan untuk dirinya.

\section{UCAPAN TERIMAKASIH}

Ucapan terimakasih penulis sampaikan yang sebesar-besarnya kepada Lembaga Penelitian dan Pengabdian Masyarakat (LPPM) Universitas Udayana yang telah mendukung dan membiayai hibah Pengabdian Masyarakat KKN PPM dengan Kontrak Pengabdian Kepada Masyarakat Kuliah Kerja Nyata Pembelajaran Pemberdayaan Masyarakat (KKN PPM) Tahun Anggaran 2017 dengan Nomor 416.35/UN14.4.A/PM/2017, tanggal 30 Maret 2017.

\section{DAFTAR PUSTAKA}

Astawa P.A, Mahardika Gede, Budaarsa K., Budiasa K.M. 2013. Sosialisasi Pengolahan Pakan Dan Kotoran Ternak Dengan Teknologi Biofermentasi. Udayana Mengabdi 12 (2): 47 - 50.

Soebarinoto. 1997. Studi Potensi Hijauan pakan dalam Rangka Pengembangan Sapi Perah di Grati. Buletin Peternakan. 2 : 142.

Sunaryo. 2014. Rancang Bangun Reaktor Biogas Untuk Pemanfaatan Limbah Kotoran Ternak Sapi Di Desa Limbangan Kabupaten Banjarnegara. Jurnal PPKM UNSIQ 1(1): 21-30 